\title{
INTERPRETATION OF THE CONCEPT OF JUSTICE IN THE ORKHON-YENISEI MONUMENTS
}

\author{
Fazilat Kholmuminovna Kasimova
}

Teacher Of The Uzbek Language And Literature, Lyceum Of Tashkent State University Of Law, Uzbekistan

\author{
ABSTRACT
}

Runic writing became widespread among the Turkic-speaking tribes of Southern Siberia, Central and Central Asia during the historical period when these tribes were part of the largest Central Asian state of the early Middle Ages — the Turkic Khaganate. The first information about the Turk tribe is contained in Chinese sources - the dynastic histories as "Zhou Shu", "Bei Qi Shu", "Sui Shu" and "Bei Shi". The Chinese spelling of the ethnonym-tujue is reconstructed as turkut; this latter form of the ethnonym is unknown in other (nonChinese) literary monuments of the VI-X centuries. According to historical sources, the design of the name Turk by the plural affix - $(y) /$, characteristic of the Mongolian languages - is a consequence of the perception of the ethnonym by the Chinese through the medium of the Mongolian-speaking Zhuan-zhuans.

KEYWORDS:- Runic writing, Turkic-speaking tribes, ethnonym, Turkic khaganate, Orkhon texts, monuments, Kul-tegin, Bilge-Kagan, inscription, Tonyukuk inscription, sarcophagus.

\section{INTRODUCTION}

The beginning of direct relations of the Turks who lived in the Altai with one of the North Chinese states - Western Wen - dates back to the middle of the VI century. In 545, the ambassador of the Western Wei emperor Taizu, a Sogdian from Jiuquan (Gansu) Anpanto, arrived at the headquarters of Prince Tujue, and the next year the reciprocal embassy "presented local works" to the imperial court.

At the same time, the Prince of the Turks Bumyn, who took the title iuiu-kehan, intervened on the side of the Zhuzhan kagan - his suzerain - in the war with the tribal union of tele and, having strengthened at the expense of the defeated tribes of this union, " broke off communication with the zhu-zhu ". The formal pretext for this act was the insulting refusal of the Zhuzhan kagan Anahuan to "establish marital kinship" with the house of Ashin (the ruling family of the Turks). As a result of the outbreak of the war, the Zhuzhans were defeated and, to a large extent, physically exterminated. On their lands in Northern Mongolia, a new Central Asian empire emerged - the Turkic Khaganate.

The political history and socio-economic structure of the first Turkic khaganate are studied in the above-mentioned works, which allows us to briefly mention here the main stages of the development of this state. After the death of Bumyn (552) and the short reign of his son Kolo was succeeded by one of the sons of Bumyn-Muhan Mwy'n of the Bugut inscription (553-572). During his reign, the Turkic Khaganate turned into a political hegemon not only in Central but also in Central Asia. In 555, the Zhuzhans were finally destroyed, the Khitan tribes and the Kyrgyz were conquered. In 563567, the Eftalite state in Central Asia was 
CURRENT RESEARCH JOURNAL OF PEDAGOGICS 2(9): 62-68, September

2021 DOI: https://doi.org/10.37547/pedagogics-crjp-02-09-14

ISSN 2767-3278

(C)2021 Master Journals

\section{Crossref do) 11 Google}

Accepted 25th September, 2021 \& Published 30 ${ }^{\text {th }}$ September, 2021

defeated. By 571, after the campaign of the Turks in Iran, the border of the khaganate was established along the Amu Darya.

A little later, in 576, a Turkic detachment captures the Cimmerian Bosporus. Mugan-Kagan

" made all the possessions lying beyond the border (the Great Wall) tremble. From the east from the Korean Gulf to the west to the Western Sea (the Caspian Sea. - S. K.) up to ten thousand li, from the south from the Sandy Steppe to the north to the North Sea (Baikal. - S. K.) from five to six thousand li - - all this expanse of land was under his power. He became a rival to the "Middle Kingdom"." The latter statement is not entirely accurate - the kaganate in this era actually turned both North Chinese states Northern Qi and Northern Zhou - into its tributaries. This dependence was especially intensified under the heir of Mugan - TasparKagan: "He had the intention to defeat the Middle State; but the court (Northern Zhou) hastened to conclude an alliance of peace and kinship with him and annually gave him 100,000 pieces of silk fabrics... The House of Qi was afraid of their raids and robberies and also depleted its treasury to pay them. Tobo (Taspar) was very proud in happiness and said to his confidants: if only in the south two boys (Northern Zhou and Northern Qi) were submissive to us - then there is no need to be afraid of poverty."

By the end of the 60s. VI century. The Turkic khaganate is included in the system of political and economic relations of the largest states of that time - Byzantium, Sasanian Iran, the Chinese Empire - and is fighting for control on the trade route from China to Western countries.

In the middle of the VI century, the Turkic tribes of Central Asia, which formed the militarypolitical core of the khaganate, approached the milestone of social development when the division of society into classes was formed. Within the khaganate, the process of formation of early feudal relations, prepared for centuries of previous development, was going on. Continuous wars of conquest temporarily muted the acute contradictions that arose during the social restructuring of the Turkic society, but the first setbacks quickly changed the situation.

In 581-588, the previously fragmented China was united under the Sui Dynasty (581-618); the reforms implemented there led to a rapid growth of the economic and military power of the empire. The strengthening of China coincided with the beginning of internecine strife within the ruling group of the kaganate after the death of Taspar-kagan (581) and a terrible famine in the steppe - " instead of bread, they used powdered bones." The growth of the wealth and influence of the Turkic aristocracy, which aspired to the autonomous management of the occupied territories, the impoverishment of the mass of ordinary community members who endured all the hardships of the war on their shoulders and lost their livelihood as a result of the jute of 581583 , the new political situation that did not give the Turkic khagans the opportunity to seek a way out in the war against China - all this led the khaganate to an acute socio-political crisis and internecine wars. The period 582-603. It ended with the collapse of the khaganate into the eastern (Central Asian) and western (Central Asian) parts, the establishment of the Sui dynasty protectorate over the Eastern Turkic Khaganate, a grueling war between the Western Turkic and Eastern Turkic khaganates, whose history after 603 went in different ways.

The crisis of the Sui Empire (613-618) and the civil war in China, which ended with the overthrow of the old dynasty and the unification of the state under the rule of emperors from the house of Tang (618-907), allowed Shibi Kagan (609-619) and his heirs Chulo Kagan, who ruled for no more than a year (619-620), and Helikagan, the younger brother of Shibi (620-630), to resume successful wars with China. However, 
CURRENT RESEARCH JOURNAL OF PEDAGOGICS 2(9): 62-68, September

2021 DOI: https://doi.org/10.37547/pedagogics-crjp-02-09-14

ISSN 2767-3278

(C)2021 Master Journals

\section{Crossref do) 11 Google}

Accepted 25th September, 2021 \& Published 30 ${ }^{\text {th }}$ September, 2021

already in 630 Emperor Taizong (626-649) defeated the Turkic troops in several battles and captured the Kheli Kagan (died in 634). From 630 to 682, the East Turkic Kaganate did not exist as an independent state.

Unlike all other runic monuments, not excluding the preserved ancient Uighur Orkhon inscriptions, the ancient Turkic Orkhon texts contain, mutually complementing each other, a coherent account of the history of the Eastern Turkic Khaganate from its creation to the beginning of decline, told on behalf of the largest figures of this state. The political bias of each of these narratives not only does not reduce, but, on the contrary, significantly increases the value of the source, since the comparison of program declarations and debatable judgments regarding certain events makes it possible to better see social conflicts and political contradictions within the kaganate than it is possible to get acquainted with the protocol description of "historical incidents" in the Chinese annals.

The historiographical aspects of the analysis of the Orkhon texts may be different. Monuments as sources for the political and social history of the Turkic Empire fix attention on the events of the internal history of the khaganate, as well as its relations with China and other Central Asian states. The significance of the Sogdian-speaking Bugut stele is great here.

In the largest monuments of Orkhon, a considerable place is occupied by references affecting the events of Central Asian history, the analysis of which allows us to outline ways to study a whole complex of historicalgeographical, historical-political and ethnological problems. In this regard, it is necessary to highlight the monuments that are of direct interest to the topic of our study. These include the most significant of the Orkhon inscriptionsthe monument in honor of Kul-tegin, the monument in honor of Bilge-Kagan, the
Tonyukuk monument, the monument in honor of Kuli-chor and to a lesser extent the Oigin inscription.

The Bugut inscription opens with the words "This stele was installed by the Turkic kings from the Ashina tribe..." In the following narrative, half destroyed by erosion, the names of the Turkic sovereigns are mentioned - Bumyn Kagan, Mugan Kagan, Taspar Kagan and Nivar Kagan. Judging by the context of the inscription, the stele was installed in honor of Taspar-kagan, who died in 581, by his co-ruler and heir NivarKagan. In 572-581, he bore the title of "small kagan" and was called Erfu-kehan in Chinese sources, and with his accession to the throne he assumed the throne name Ishbar-kagan (sHabollo-kehan from Chinese sources, 581587).

The monuments to Kul-tegin and Bilge-Kagan were discovered by H. M. Yadrintsev in 1889 in the Koshcho-Tsaydam tract, on the bank of the Kokshin-Orkhon, $400 \mathrm{~km}$ west of Ulaanbaatar, 25 $\mathrm{km}$ south of the lake. Ugey-nor and $40 \mathrm{~km}$ north of the ruins of Karabalgasun. In 1890, the monument was examined by the expedition of G. Geikel, in 1891-by the expedition of V. V. Radlov. In 1902, the monument was examined and described by the English consul in Wuzhou, K. Campbell, and in 1909 - by the French traveler de Lacoste. In 1912, the monuments were examined by V. L. Kotvich. In I960, the monuments were again examined by E. I. Ubryatova and V. M. Nadelyaev. In 1968-1969. The Koshotsaydam monuments were examined by S. G. Klyashtorny.

The burial complex associated with the monument to Kul-tegin was first subjected to a detailed, albeit incomplete, archaeological survey only in 1958 by a Mongolian-Czechoslovak expedition; the excavations were led by the Czech archaeologist L. Yisl. The results of the work of this expedition, as well as information 
CURRENT RESEARCH JOURNAL OF PEDAGOGICS 2(9): 62-68, September

2021 DOI: https://doi.org/10.37547/pedagogics-crjp-02-09-14

ISSN 2767-3278

(C)2021 Master Journals

\section{Crossref do) 11 Google}

Accepted 25th September, 2021 \& Published 30 ${ }^{\text {th }}$ September, 2021

from Chinese sources and the inscriptions themselves, allow us to get some idea of the original appearance of the burial structures and their history.

Kül-tegin died at the age of 47, on February 27, 731. In May of this year, Bilge-Kagan appealed to Emperor Xuanzong with a request to hire Chinese craftsmen and artists to build a temple and make an image of Kul-tegin •'

The narration is conducted in the name of Bilgekagan; the inscriptions are his "word", his "speech", addressed to the "Turkic begs and people", to the "begs and people of the TokuzOguz", to the conquered tribes.

In the" small inscriptions", which are not only an introduction, but also a summary of the" big ones", Bilge-Kagan, briefly mentioning the distant campaigns he made" for the benefit of the Turkic people", warns those who listen to him against" evil people " who are flattered by the rich gifts of the Chinese emperor and advise the Turks to move to the south, i.e. to submit to China. It recalls the recent past, when the "Turkic people" "completely exhausted and exhausted" under the rule of the "kagan of the Tabgach people". Only in the Otyuken rabble, inaccessible to Chinese troops, the Turks can feel calm and maintain friendly relations with China, receiving rich gifts from there. In order for the "Turkic people" to remember how he, Bilge-Kagan, "made the poor people rich, the few people made numerous", so that the "Turkic people" knew what they should fear and what to follow, the "speech" of the kagan is imprinted on the "eternal stone": "0 Turkic run and people, listen to this! I have carved here how you (run and the people), having gathered the Turkic people, created (your) state, how you, having erred, shared, I have carved everything here. All that I (had) To say, I carved on the eternal stone. Looking at it, know (learn) you, the present run and the people!".
The "large inscriptions" of both monuments are dedicated to the historical narrative that BilgeKagan begins from ancient times: "When the blue sky appeared above and the brown earth below, the sons of men appeared between (them) both. My ancestors Bumyn-Kagan, Istemi-Kagan sat over the sons of men. Having settled (on the kingdom), they created and supported the state and the establishment of the Turkic people. The four corners of the world were all their enemies; when they marched with an army, they conquered all the peoples of the four corners of the world... So they reigned... establishing order among the blue Turks, who previously had neither a master nor (an organization for) "Arrows". They were wise kagans, they were courageous kagans, and their buyurukas were, one must think, wise, they were, one must think, courageous, and their begi and the people were straight (unanimous). That is why, I think, they ruled the state for so long and, while governing the state, established laws. Then they died... After them, their younger brothers became kagans, and then their sons became kagans. After that, since the younger brothers were not like the older ones, and the sons were not like their fathers, it is necessary to think that the foolish kagans sat down (on the kingdom), and their buyuruk were also unreasonable, were cowardly. Due to the indirect (infidelity to the Kagan) of the begs and the people, due to the deception and incitement of deceivers from the Chinese people and their machinations, due to the fact that they quarreled with younger brothers with their elders, and the people with the begs, the Turkic people upset their previously existing state and brought ruin on the reigning kagan; they became slaves to the Chinese emperor with their strong sons, slaves with their pure daughters".

This is how Bilge-Kagan tells about the creation and decline, rise and collapse of the first Turkic state, the time of its emergence seemed to be legendarily distant in the VIII century. 
CURRENT RESEARCH JOURNAL OF PEDAGOGICS 2(9): 62-68, September

2021 DOI: https://doi.org/10.37547/pedagogics-crjp-02-09-14

ISSN 2767-3278

(C)2021 Master Journals

\section{Crossref do) 11 Google}

Accepted 25th September, 2021 \& Published 30 ${ }^{\text {th }}$ September, 2021

The divine will, the manifestation of which is the power of the kagan, the loyalty to the kagan of the begs and the people, the subordination of the people to the begs - this is the leitmotif of the ideas that permeate both inscriptions, these are the basic conditions for the existence of the "eternal ale". As if summarizing the history lesson taught to his listeners and readers, Bilgekagan in another place of the inscription sums up what was said: "If you, the Turkic people, do not separate from your kagan, from your races, from your homeland... you yourself will live happily, you will be in your homes, you will live carelessly" . These lines clearly express the essence of the ideology of the aristocratic elite of the Turkic Khaganate, the inscription insistently demands the absolute submission of the people to the kagan and the begs - and at the same time, the entire text of the monuments should serve, according to the author, as a justification and confirmation of this idea. The well-being of the "Turkic people" is the result of submission to the kagan, who, along with fleeing from the Otyuken rabble, sends troops on victorious campaigns, rewards the people with loot and tribute to the conquered tribes: "...their gold and shiny silver, their well-woven silks, their drinks extracted from grain, their riding horses and stallions, their black sables and blue squirrels, I got for my Turkic people!".

The first seven lines of the "big inscriptions" in honor of Kul-tegin and Bilge-kagan are dedicated to the first Turkic khaganate. The dynastic strife and the struggle of the people against the Begs led to the death of the last kagan, who, like his closest predecessors, did not show either sufficient intelligence or sufficient courage. The death of the kagan, whatever he was, eventually brought the "Turkic people" to the brink of destruction, but Heaven took pity and sent him a savior - Ilterish Kagan, the father of Bilge Kagan. In fierce battles, Ilterish revived the Turkic ale . The Kapagan-kagan who succeeded him further raised the power and welfare of the "Turkic people". However, the people did not appreciate their happiness - they fell into turmoil, allowed the death of the kagan, again turned into a "pathetic and low" people. Becoming a kagan in such an environment, Bilge "did not sleep at night and did not sit (idle) during the day." Twelve times he went on campaigns and revived the ale and glory of the "Turkic people", "raised the people ready to perish to life, provided the naked people with a dress, made the poor people rich, made the small people numerous". Bilge-Kagan's closest associate and associate was his brother Kultegin.

The battles and campaigns in which Kul-tegin participated, about his deeds and exploits, about his death and funeral, about the grief of Bilgekagan are told in the 30-53 lines of the inscription. This part of the narrative begins with a description of the first campaign in which the 16-year-old prince participated - a campaign against the "Sogdaks" in 701, and in lines 44-50 tells about the most glorious deeds of the knight his battles with the Tokuz-Oguz in 724, when Kul-tegin saved the headquarters and the kagan's family. However, the description of successful battles that took place after 716 , i.e. after the accession to the throne of Bilge-Kagan, it was transferred mainly to the inscription of the kagan himself ; the kagan devotes only six lines to his exploits before his accession to the throne.

In the 51st line of the large inscription in honor of Bilge-kagan, the" speech " on behalf of Bilgekagan is interrupted; lines 51-56, as well as the poorly preserved inscription on the shield of the monument, are written on behalf of the son and heir of Bilge-Kagan. Perhaps he also owns the inscription on one of the carved faces of the monument (XII) and the inscription on the shield. Lines 51-56 contain the dates of the death and funeral of Bilge-Kagan, a description of the memorial gifts, the hierarchy of the races 
CURRENT RESEARCH JOURNAL OF PEDAGOGICS 2(9): 62-68, September

2021 DOI: https://doi.org/10.37547/pedagogics-crjp-02-09-14

ISSN 2767-3278

(C)2021 Master Journals

\section{Crossref do) 11 Google}

Accepted 25 $5^{\text {th }}$ September, 2021 \& Published 30 ${ }^{\text {th }}$ September, 2021

standing around the Kagan throne.

The Tonyukuk inscription was discovered by E. N. Klements in 1897. In 1898, prints and photographs of the inscription were made, according to which V. V. Radlov carried out the publication of the monument and the first translation of the texts. Later, the monument was examined by G. Ramstedt (1909), B. Ya. Vladimirtsov (1925), P. Aalto (1957), E. I. Ubryatova and V. M. Nadelyaev (1960), S. G. Klyashtorny (1968, 1969). The monument is located in the Bain-Tsokto tract, $66 \mathrm{~km}$ southeast of Ulaanbaatar, between the settlement of Nalaykha and the right bank of the Tola River. As in Kosho-Tsaydam, the inscription is part of a funerary memorial complex, which also includes the ruins of a funeral temple, a square sarcophagus of marble slabs half-buried in the ground, decorated with ornaments, a small sarcophagus, eight human figures carved from stone and a chain of stones (balbals) adjacent to the temple from the east.

According to its content, the inscription is Tonyukuk's autobiography written in panegyric tones, told against the background of historical events, of which he was an active participant. At the same time, the inscription contains not only a description, but also an interpretation of these events, their political assessment.

In the 1st line of the Tonyokuk reports that he was born or educated in China, at a time when the entire "Turkic people" were "subordinate to the Chinese state". Next, the story of the great Turkic uprising is told, as a result of which the second Eastern Turkic Khaganate emerged. Lines 20-48 - a vivid description of the wars with the Kyrgyz and Turgesh and the campaign in Sogd. The final lines of the inscription are an unrestrained praise of their own deeds and merits, without which, according to Tonyukuk, the emergence and existence of the Turkic state would have been impossible.
The Kuli-chor inscription is no exception - in three of the four large inscriptions in the monuments of Kul-tegin, Bilge-Kagan and Onga inscriptions, the ancestors of the heroes are mentioned in one form or another, and quite detailed information is provided about their parents. Only the inscription of Tonyukuk Kulichor is dedicated exclusively to its author, his life and deeds.

Thus, in the 1st-3rd lines of the inscription, it is briefly told about the grandfather-Ishvar Chykan Kuli-chor, who died at the age of eighty during the reign of Kapagan-kagan, i.e. before 716. In the 4th -17 th lines, the exploits of his son Chavush Bilge Kuli-chor are reported, his battles with the Tokuz - Oguz, the campaign for the Pearl River (Syr-Darya) (712-719), Tatabs (722-723)are mentioned; it was he who was present at the head of the Tardush begs at the accession of Bilge-Kagan to the throne, participated in four battles near Beshbalyk - this is also mentioned in the inscriptions of Taihir-chulu (Hoyt-Tamir): "We will go to Beshbalyk with Kuli-chor Tardushsky, so let him be happy!"

In lines 18-23 - the life of the younger Kulichor, his first childhood exploits - at the age of seven he killed a mountain goat, at the age of nine-a wild boar; his battles with the Karluks and his death in battle. Lines 24-27 describe his funeral; the younger brother of Bilge-kagan, Edchortegin, four more tegins and the son of Kuli-chor, Yegen-chor, participated in the funeral rites; the construction of funeral structures is also reported here.

The mention of the name of Bilge-Kagan gives reason to consider the time of creation of the inscription 734. It is obvious that the monument was built after 723 (the war with the Tatabs) and before 725, when the wars with the Tokuz-Oguz, whose allies were the Karluks, ended (or shortly after 725). These dates generally coincide with the chronological calculations of J. Kloson, E. 
CURRENT RESEARCH JOURNAL OF PEDAGOGICS 2(9): 62-68, September

2021 DOI: https://doi.org/10.37547/pedagogics-crjp-02-09-14

ISSN 2767-3278

(C)2021 Master Journals

\section{Crossref do) 81 Google}

Accepted 25th September, 2021 \& Published 30 ${ }^{\text {th }}$ September, 2021

Triyarsky and L. Bazin.

\section{Results AND DISCUSSIONS}

The reconstruction and new translation of the inscription from Ihe Khushotu undoubtedly change its historiographical assessment among other large Orkhon monuments. If earlier the ambiguity of the presentation of the course of events that were associated with the biography of one person allowed for a lot of arbitrary assumptions, then as a result of the new interpretation of the text, the chronological framework of the narrative and their connection with the events mentioned in the Koshotsaydam steles, in the Tonyukuk monument, in the Taihirchulu inscriptions are quite confidently determined.

Ambiguities in the interpretation of the inscription due to the small possibilities of text reconstruction caused a lot of contradictory judgments regarding the content and attribution. Three issues remained the most controversial: a) in whose honor is the monument erected? b) who is its author? c) when is the monument erected or when is the text written?

According to V. V. Radlov, the hero of the inscription is Ilterish-kagan (Kutlug), who is also called Tacham. The year of the Dragon mentioned in the inscription is the year of the death of Ilterish-kagan (692). Consequently, the monument was erected in honor of IlterishKagan in the following year, 693. This attribution was preserved for a very long time in the special literature, undergoing only minor adjustments; the Onginsky monument was considered the earliest of the Orkhon texts.
Kagan, Tonyukuk. International Club Abaya. - Semey, 2001.

2. V. V. Radlov, P. M. Melnoransky, V. V. Barthold, S. E. Malov, A. N. Bernstam, S. V. Kiselev, L. A. Yevtyukhova, A. N. Kononov, N. A. Baskakov, E. I. Ubryatova, A. M. Shcherbak, I. V. Stebleva, L. V. Kyzlasov, S. G. Klyashtorny, A. D. Grach, S. I. Weinstein and others.

3. Bernstam A. N. socio-economic construction of orkhono-Yenisei Turok VIVIII vekov: Vostochno-turksky kaganat and kyrgyzy. Moscow: izd-Vo an USSR publ., 1946.

4. Bernstam A. N. Istoki Kirghiz literature. Frunze, 1945.

5. Auezov M. A. Kyrgyz heroic poem "Manas". "What?": Kyrgyz heroic epic "Manas". Moscow: izd-Vo an USSR, 1961; Bogdanova M. I. Kirghizskaya Literatura. Moscow: Sovetsky pysatel publ., 1947.

6. Chelekenov U. H. settled civilization of the Turks. - Almaty: Kazakh University, 2003.

7. Newspaper "Aikyn". - 45(741). - March 14. $-2007$.

8. Nasilov V. M. The language of the OrkhonYenisei monuments. M., 1960;

9. Stebleva I. V. Poetry of the Turks of the VIVIII centuries, Moscow, 1965;

10. Tekin T. A grammar of Orkhon Turkish. The Hague, 1968.

11. Rasuljanovna, I. N., \& Rakhmonqulovich, K. N. (2020). Trade Relations Between Ancient Bacteria And China On The II-I BC. The American Journal of Social Science and Education Innovations, 2(07), 47-51.

\section{REFERENCES}

1. Orkhonsky nadpisi. Kule-Tegin, Bilge- 